\title{
CONTROL OF PORE SIZE AND STRUCTURE OF TISSUE ENGINEERING SCAFFOLDS PRODUCED BY SUPERCRITICAL FLUID PROCESSING
}

\author{
Hongyun Tai ${ }^{1,2}$, Melissa L. Mather ${ }^{3}$, Daniel Howard ${ }^{2}$, Wenxin Wang ${ }^{1}$, Lisa J. White ${ }^{2}$, John A. Crowe ${ }^{3}$, Steve P. \\ Morgan $^{3}$, Amit Chandra ${ }^{4}$, David J. Williams ${ }^{4}$, Steven M. Howdle ${ }^{1 *}$ and Kevin M. Shakesheff ${ }^{2}$ \\ ${ }^{1}$ School of Chemistry, ${ }^{2}$ School of Pharmacy, ${ }^{3}$ School of Electrical and Electronic Engineering, The University of \\ Nottingham, University Park, Nottingham, NG7 2RD \\ ${ }^{4}$ School of Mechanical and Manufacturing Engineering, The University of Loughborough, Loughborough, \\ Leicestershire, UK, LE11 3TU
}

\begin{abstract}
Tissue engineering scaffolds require a controlled pore size and structure to host tissue formation. Supercritical carbon dioxide $\left(\mathrm{scCO}_{2}\right)$ processing may be used to form foamed scaffolds in which the escape of $\mathrm{CO}_{2}$ from a plasticized polymer melt generates gas bubbles that shape the developing pores. The process of forming these scaffolds involves a simultaneous change in phase in the $\mathrm{CO}_{2}$ and the polymer, resulting in rapid expansion of a surface area and changes in polymer rheological properties. Hence, the process is difficult to control with respect to the desired final pore size and structure. In this paper, we describe a detailed study of the effect of polymer chemical composition, molecular weight and processing parameters on final scaffold characteristics. The study focuses on poly(DL-lactic acid) $\left(\mathrm{P}_{\mathrm{DL}} \mathrm{LA}\right)$ and poly(DL-lactic acid-coglycolic acid) (PLGA) as polymer classes with potential application as controlled release scaffolds for growth factor delivery. Processing parameters under investigation were temperature (from 5 to $55^{\circ} \mathrm{C}$ ) and pressure (from 60 to 230 bar). A series of amorphous $\mathrm{P}_{\mathrm{DL}}$ LA and PLGA polymers with various molecular weights (from $13 \mathrm{KD}$ to $96 \mathrm{KD}$ ) and/or chemical compositions (the mole percentage of glycolic acid in the polymers was $0,15,25,35$ and 50 respectively) were employed. The resulting scaffolds were characterised by optical microscopy, scanning electron microscopy (SEM), and micro X-ray computed tomography $(\mu \mathrm{CT})$. This is the first detailed study on using these series polymers for scaffold formation by supercritical technique. This study has demonstrated that the pore size and structure of the supercritical $\mathrm{P}_{\mathrm{DL}} \mathrm{LA}$ and PLGA scaffolds can be tailored by careful control of processing conditions.
\end{abstract}

Key Words: poly(DL-lactic acid) ( $\left.\mathrm{P}_{\mathrm{DL}} \mathrm{LA}\right)$, poly(lactic acidco-glycolic acid) (PLGA), supercritical carbon dioxide $\left(\mathrm{scCO}_{2}\right)$, plasticization, foaming, scaffolds

\footnotetext{
*Address for correspondence:

Steven M. Howdle

School of Chemistry

The University of Nottingham

University Park

Nottingham, NG 7 2RD, UK
}

Email: steve.howdle@nottingham.ac.uk

\section{Introduction}

In tissue engineering, a porous scaffold is required to act as a template and guide for cell proliferation, differentiation and tissue growth. Scaffolds may also act as controlled release devices that deliver growth factors with rates matching the physiological need of the regenerating tissue (Langer, 1998). Poly(lactic acid) (PLA) and associated poly(lactic acid-co-glycolic acid) (PLGA) copolymers are commonly used biodegradable polymers for fabricating tissue engineering porous scaffolds. PLGA copolymers with various polymer compositions (the ratio of lactic acid and glycolic acid content in the polymer) degrade at different rates. Therefore, it is of great interest using PLGA copolymers to make scaffolds for various applications. These polymers degrade in vivo and eventually disappear at a desired rate while the native tissues grow and the degradation residues are discharged through rental filtration. Moreover, the release of encapsulated growth factors from these materials depends on both diffusion and degradation.

Common scaffold fabrication techniques include solvent casting/salt leaching (Lu et al., 2000; Murphy et al., 2002), moulding/salt leaching (Hou et al., 2003; Sosnowski et al., 2006) and gas foaming agent/salt leaching (Kim et al., 2006; Nam et al., 2000). These conventional methods require the use of organic solvents and/or elevated processing temperatures which can prohibit their use in the preparation of growth factor loaded scaffolds. Additionally, the salt leaching process may lead to the removal of a proportion of the growth factor dose during prolonged leaching (Hutmacher, 2000). To overcome these limitations, carbon dioxide $\left(\mathrm{CO}_{2}\right)$ has been used as a plasticiser and foaming agent to form threedimensional (3-D) scaffolds (Barry et al., 2004; Barry et al., 2006; Harris et al., 1998; Hile et al., 2000; Hile and Pishko, 2004; Howdle et al., 2001; Mooney et al., 1996; Quirk et al., 2004; Singh et al., 2004; Watson et al., 2002; Yang et al., 2004). $\mathrm{CO}_{2}$ is inexpensive, non-toxic and nonflammable and readily available in high purity from a variety of sources. Supercritical carbon dioxide, $\mathrm{scCO}_{2}$, $\left(\mathrm{T}_{\mathrm{c}}=31.1^{\circ} \mathrm{C}, \mathrm{P}_{\mathrm{c}}=73.8 \mathrm{bar}\right)$ has the combination of gaslike diffusivity and liquid-like density, which makes $\mathrm{scCO}_{2}$ a unique medium for polymer synthesis and polymerprocessing (Cooper 2001; Tomasko et al., 2003; Woods et al., 2004). The addition of small amounts of compressed $\mathrm{CO}_{2}$ to polymer phases can result in substantial and 
Table 1: $\mathrm{P}_{\mathrm{DL}}$ LA and PLGA polymer characteristics.

\begin{tabular}{llllllll}
\hline Polymers & Resource & Form & $\begin{array}{l}\text { Composition } \\
\text { (L:G) }\end{array}$ & $\begin{array}{l}\text { Inherent } \\
\text { viscosity } \\
(\mathbf{d L} / \mathbf{g})\end{array}$ & $\begin{array}{l}\mathbf{M}_{\mathbf{w}}^{\mathbf{a}} \\
\text { (KD) }\end{array}$ & PDI $^{\mathbf{b}}$ & $\begin{array}{l}\mathbf{T}_{\mathbf{g , D s c}} \mathbf{c}^{\mathbf{c}} \\
\left.\mathbf{(}^{\mathbf{0}} \mathbf{C}\right)\end{array}$ \\
\hline $\mathrm{P}_{\text {DL }}$ LA(52K) & Purac & Granular & $100: 0$ & 0.52 & 52 & 1.87 & 46.9 \\
\hline PLGA 85:15(15K) & Lakeshore & Pellet & $85: 15$ & 0.18 & 15 & 1.76 & 40.2 \\
PLGA 85:15(39K) & Lakeshore & Pellet & $85: 15$ & 0.41 & 39 & 1.81 & 49.2 \\
PLGA 85:15(77K) & Lakeshore & Pellet & $85: 15$ & 0.63 & 77 & 1.70 & 48.6 \\
PLGA 85:15(96K) & Lakeshore & Pellet & $85: 15$ & 0.73 & 96 & 1.70 & 49.5 \\
\hline PLGA 75:25(13K) & Resomer & Fine powder & $75: 25$ & $0.16-0.24$ & 13 & 1.89 & 37.6 \\
PLGA 75:25(72K) & Resomer & Fine powder & $75: 25$ & $0.5-0.7$ & 72 & 1.75 & 50.4 \\
\hline PLGA 65:35(52K) & Lakeshore & Granular & $65: 35$ & 0.5 & 52 & 1.69 & 49.1 \\
PLGA 65:35(82K) & Lakeshore & Granular & $65: 35$ & 0.66 & 82 & 1.69 & 43.6 \\
\hline PLGA 50:50(53K) & Resomer & Fine powder & $50: 50$ & 0.55 & 53 & 1.59 & 47.0 \\
\hline
\end{tabular}

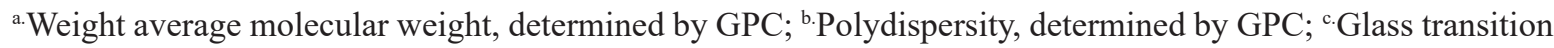
temperature, determined by DSC.

dramatic changes in the physical properties, including viscosity, permeability, interfacial tension and glass transition temperature $\left(\mathrm{T}_{\mathrm{g}}\right)$. Mooney et al. (1996) formed PLGA scaffolds (the mole ratio of lactic acid and glycolic acid $(\mathrm{L} / \mathrm{G})$ was $50: 50)$ by a $\mathrm{CO}_{2}$ pressure quenching method. The preformed PLGA polymer discs were saturated in $\mathrm{CO}_{2}$ at a pressure of 55 bar and ambient temperature $\left(20-23^{\circ} \mathrm{C}\right.$ ) for a prolonged time (48 to 72 hours). This was followed by a rapid depressurisation (e.g. seconds). The foams produced had pores of approximately $100 \mu \mathrm{m}$ in diameter and porosities up to $93 \%$, but had low interconnectivity. It was further reported that the combination of $\mathrm{CO}_{2}$ gas foaming and salt leaching technique (GF/SL) led to scaffolds with open pore structures (Harris et al., 1998; Riddle and Mooney, 2004). Subsequently, PLGA copolymers with various compositions, $\mathrm{L} / \mathrm{G}$ ratios of 85:15, 75:25, 65:35 and 50:50, were employed to fabricate porous scaffolds by the GF/ SL technique for the controlled delivery of vascular endothelial growth factor (VEGF) (Murphy et al., 2000; Sheridan et al., 2000), DNA (Jang and Shea, 2003) and as a support for 3-D culture of cells (Quirk et al., 2004). Pishko and co-workers (Hile et al., 2000; Hile and Pishko, 2004) also produced PLGA (L/G ratio as 80:20 and 65:35) scaffolds using water-in-solvent emulsion (aqueous protein phase and organic polymer solution phase) via a $\mathrm{CO}_{2}$ pressure quenching method at conditions in the supercritical region $\left(35^{\circ} \mathrm{C}, 80\right.$ bar $)$ for a prolonged saturation time (24 hours) to deliver basic fibroblast growth factor (bFGF).

By contrast, we have developed a single step supercritical carbon dioxide $\left(\mathrm{scCO}_{2}\right)$ foaming process using polymer powder samples to generate porous scaffolds (Howdle et al., 2001). This novel $\mathrm{scCO}_{2}$ foaming process has been carried out at high pressure (170-230 bar) and short soaking times ( $0.5-2$ hours) with a controlled venting rate (venting time between 2 minutes and 2 hours) at $35^{\circ} \mathrm{C}$ (Barry et al., 2004; Barry et al., 2006; Howdle et al., 2001; Quirk et al., 2004; Watson et al., 2002; Yang et al., 2004). The produced scaffolds with an interconnected porous structure (pore size ca. 200-500 $\mu \mathrm{m}$ and porosity ca. 60 $80 \%$ ) have been studied for growth factor and gene delivery. For example, bone morphogenetic protein 2
(BMP-2) has been encapsulated into $\mathrm{P}_{\mathrm{DL}}$ LA scaffolds for bone tissue engineering by this supercritical fluid mixing and foaming technique (Yang et al., 2004). Bone formation was observed due to the release of the osteoinductive protein BMP-2 from $\mathrm{P}_{\mathrm{DL}}$ LA scaffolds both in vitro and invivo (Yang et al., 2004; Yang et al., 2006). These scaffolds have also been used to study adenoviral gene transfer into primary human bone marrow osteoprogenitor cells (Partridge et al., 2002; Howard et al., 2002). Recently, polyamidoamine (PAA)/DNA complexes have been incorporated into supercritical $\mathrm{P}_{\mathrm{DL}}$ LA scaffolds; these exhibited a slow release and extended gene expression profile (Heyde et al., 2007).

Scaffolds with a desired pore size, porosity and interconnectivity are required by various tissue engineering applications because the pore structure strongly influences cell growth and drug release profile. However, the process of forming scaffolds by supercritical fluid technique is difficult to control with respect to changes in final pore size and structure. In this paper, a series of poly(DL-lactic acid) $\left(\mathrm{P}_{\mathrm{DL}} \mathrm{LA}\right)$ and poly(DL-lactic acid-co-glycolic acid) (PLGA) polymers were employed for a detailed study of the effect of polymer composition, molecular weight and processing parameters on final scaffold characteristics.

\section{Experimental}

\section{Materials}

In this study, a series of amorphous $\mathrm{P}_{\mathrm{DL}}$ LA and PLGA polymers with different inherent viscosity and compositions were purchased from Boehringer Ingelheim (Resomer, Germany), Purac (Gorinchem, the Netherlands) and Lakeshore Biomaterials (Birmingham, AL, USA) in the forms of fine powder, granular or pellet, and used as received (Table 1). Weight-average molecular weights $\left(\mathrm{M}_{\mathrm{w}}\right)$ and the polydispersity (PDI) of these polymers were measured by Gel Permeation Chromatography (GPC) (PL120, Polymer Laboratories Ltd., Church Stretton, Shropshire, UK) with a refractive index (RI) detector. The columns (30 cm PLgel Mixed-C, two in series) were eluted by tetrahydrofuran (THF) and calibrated with narrow molecular weight distribution polystyrene standards. All calibrations and analyses were performed at $40^{\circ} \mathrm{C}$ with a 
flow rate of $1 \mathrm{ml} / \mathrm{min}$. The glass transition temperatures $(\mathrm{T})$ of these polymers were determined utilising a TA 2920 Differential Scanning Calorimeter (DSC). The tests were performed from -10 to $120^{\circ} \mathrm{C}$, at a heating rate of $10^{\circ} \mathrm{C} /$ min. Food grade $\mathrm{CO}_{2}$ was supplied by Cryoservice and used without further purification.

\section{Scaffolds production by $\mathrm{CO}_{2}$ foaming technique}

$130 \mathrm{mg}$ of polymer was weighed into each well of a Teflon mould (12 wells with $10 \mathrm{~mm}$ diameter and $10 \mathrm{~mm}$ height, no top-lid, made in house) as described previously (Quirk et al., 2004). This mould was designed with a detachable base to allow easy removal of scaffolds after fabrication. The mould was then placed into a $60 \mathrm{~mL}$ clamp sealed stainless steel high-pressure autoclave (made in house) (Furno et al., 2003). The autoclave was equipped with a pressure transducer for pressure monitoring and a heating jacket with a CAL 3300 temperature controller for temperature control. HIP high pressure valves and Swagelok tubing and fittings were adopted to connect the system. A high pressure PM101 pump (New Ways of Analytics, Lörrach (Baden-Württemberg), Germany) was used to charge $\mathrm{CO}_{2}$ into the autoclave. The vessel was heated or cooled to a desired temperature $(\mathrm{T})$, and then pressurised to a certain pressure $(\mathrm{P})$ over a period of filling time (FT). After the polymer/ $\mathrm{CO}_{2}$ mixture was maintained at the constant pressure $\mathrm{P}$ for a desired soaking time (ST), the vessel was then depressurised to ambient pressure over a period of venting time (VT). The three stages of the scaffold production process, i.e. filling, soaking and venting, were controlled by a backpressure regulator (BPR, Bronkhorst, the Netherlands) via a computer program. Porous scaffolds with a layer of nonporous skin and the size of approximately $10 \mathrm{~mm}$ diameter and 5-10 $\mathrm{mm}$ height were generated by this procedure. It is worth to mention that for cell seeding and drug release studies, the nonporous skin of the scaffolds should be removed by cutting with a scalpel blade.

\section{Characterisation of scaffolds}

Microscope optical images of scaffolds were captured using a Cool Snap Pro digital camera equipped with a Nikon (Kingston-upon-Thames, U.K.) AF Micro Nikkor $60 \mathrm{~mm}$ f/2.8D lens and interfaced through a CoolSnap Pro PCI interface card (MDS, Toronto, Canada) to a Pentium PIII 1Ghz PC. The images were acquired and processed using image analysis software (Image Pro Plus 4.5, Media Cybernetics, Bethesda, MD, USA).

Scanning Electron Microscopy (SEM) was used to determine the foam morphology of scaffolds at the cross section. A scalpel blade was used to cut the scaffold in half vertically. The sample was mounted on an aluminium stub using an adhesive carbon tab and sputter coated with gold before images were obtained using a JEOL (Tokyo, Japan) JSM-6060LV SEM machine.

Micro X-ray Computed Tomography (Micro-CT) images were obtained using a high resolution micro-CT system ( $\mu \mathrm{CT} 40$, Scanco Medical, Bassersdorf, Switzerland). Scaffolds were mounted on a rotary stage inside the micro-CT apparatus and scanned. The scanner was set to a voltage of $55 \mathrm{kV}$ and a current of $143 \mathrm{~mA}$. The resulting 2-D images were used to construct 3-D images.

\section{Results and Discussion}

\section{Visual observation of plasticisation and foaming process}

A double headed clamp sealed view cell $(100 \mathrm{ml})$ with a sapphire widow was used to carry out visual observations. The images were captured by a Thorlabs (Newton, NJ, USA) CCD (couple charged device) camera. A small glass vial (10 $\mathrm{mm}$ diameter and $10 \mathrm{~mm}$ height) was used as the container for the polymer sample. The production of a scaffold was carried out as described in the experimental section. When the $\mathrm{CO}_{2}$ was charged into the vessel, a decrease of the apparent volume of the solid sample was observed, indicating that the polymer sample was plasticised into a liquid-like state, which was denser than a loose packed powder or pellet sample. This plasticsation took place rapidly (within minutes) depending on the soaking pressure employed. It occurred immediately after the pressure reached 230 bar, and within 10 minutes for a lower pressure of 50 bar. The plasticised polymer was a transparent liquefied polymer melt (Figure 1a). Upon depressurisation, the transparent swollen polymer became opaque from the top surface to the bottom of the polymer/ $\mathrm{CO}_{2}$ mixture (Figure $1 \mathrm{~b}$ ), indicating phase separation had occurred in the polymer/ $\mathrm{CO}_{2}$ mixture. A liquid and gas boundary in the sample container was clearly observed (Figure 1c) during rapid depressurisation because the
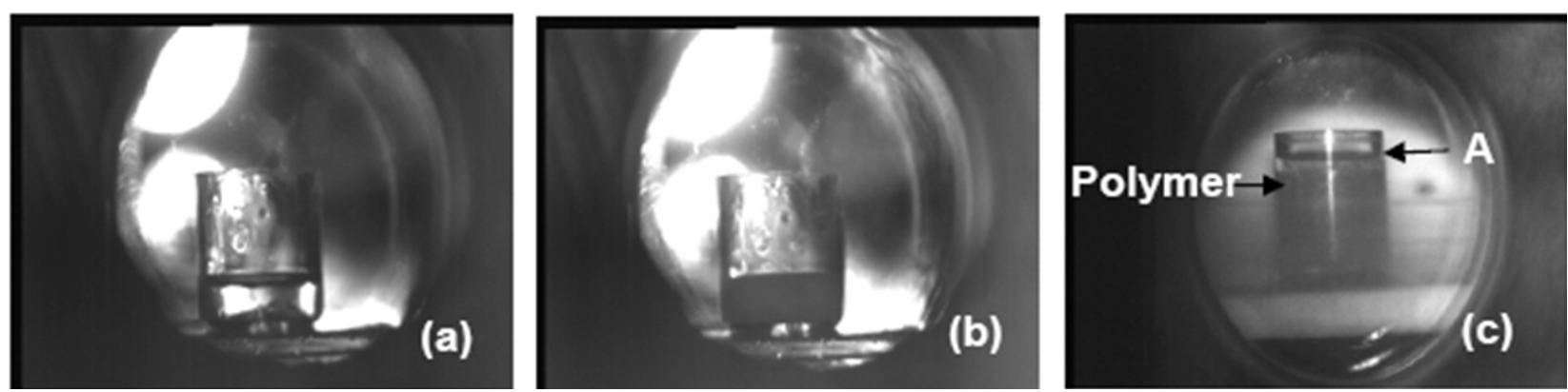

Figure 1: View cell observations: (a) plasticised polymers appeared to be transparent liquefied polymer melts; (b) plasticised polymers became opaque while venting occurred, indicating phase separation and gas nucleation; (c) phase separation observed in $\mathrm{CO}_{2}$ fluid phase while fast venting was operated. A liquid/gas boundary (A) in the sample container was clearly observed. 
Table 2: Pore diameter $(\mu \mathrm{m})$ and porosity $(\%)$ of scaffolds fabricated at $\mathrm{T}=35^{\circ} \mathrm{C}, \mathrm{P}=230$ bar, $\mathrm{FT}=20$ minutes, $\mathrm{ST}=60$ minutes, $\mathrm{VT}=60$ minutes.

\begin{tabular}{lllll}
\hline & & \multicolumn{2}{l}{ Pore Diameter $^{\mathbf{a}}$} \\
\cline { 3 - 4 } & & $\begin{array}{l}\text { Mean } \\
(\boldsymbol{\mu m})\end{array}$ & $\begin{array}{l}\text { SD }^{\mathbf{b}} \\
(\boldsymbol{\mu m})\end{array}$ & \multicolumn{1}{c}{ Porosity \% $^{\mathbf{c}}$} \\
\hline 1 & Polymers $_{\text {DL }}$ LA(52K) & 580.1 & 154.0 & 78 \\
2 & PLGA 85:15(39K) & 323.9 & 101.3 & - \\
3 & PLGA 85:15(77K) & 199.4 & 46.0 & 70 \\
4 & PLGA 85:15(96K) & 81.9 & 25.4 & - \\
5 & PLGA 75:25(72K) & 70.6 & 16.4 & 72 \\
6 & PLGA 65:35(52K) & 65.1 & 11.1 & 78 \\
7 & PLGA 65:35(81K) & 49.4 & 11.8 & - \\
8 & PLGA 50:50(53K) & 38.8 & 8.7 & 34 \\
\hline
\end{tabular}

a Determined by SEM; ${ }^{\mathrm{b}}$ Standard deviation; ${ }^{\mathrm{c}}$ Determined by Micro CT, standard deviation 2\%.

temperature in the vessel dropped dramatically leading to a phase separation in the $\mathrm{CO}_{2}$ fluid phase. The expansion of opaque polymers into foams was observed while venting continued.

\section{Effect of molecular weight and chemical composition of $P_{D L}$ LA and PLGA polymers}

To study the effect of molecular weight and the composition of the polymers, scaffolds were fabricated using a series of $\mathrm{P}_{\mathrm{DL}}$ LA and PLGA polymers (Table 1) under the same fabrication conditions at $\mathrm{T}=35^{\circ} \mathrm{C}, \mathrm{P}=230$ bar, FT $=20$ minutes, $\mathrm{ST}=60$ minutes and $\mathrm{VT}=60$ minutes. The results demonstrate that the pore size of the scaffolds produced decreases with increasing molecular weight (Table 2, entries 2-4 for PLGA 85:15 and entries 6-7 for PLGA 65:35). Moreover, the pore size decreases with increasing glycolic acid content (Figure 2 and Table 2 , entries $1,3,5,6,8)$. The SEM images of the $\mathrm{P}_{\mathrm{DL}} \mathrm{LA}$ scaffolds showed more open and interconnected pore structures than for the PLGA scaffolds (Figure 2). The pore size distribution of the porous scaffolds, determined by micro $\mathrm{CT}$, is much narrower for those produced from PLGA copolymers than those from $\mathrm{P}_{\mathrm{DL}}$ LA homopolymer. There is also a trend in the pore size distribution which becomes narrower with increasing glycolic acid content of the copolymers (Figure $3 \mathrm{a}$ ). The porosity of $\mathrm{P}_{\mathrm{DL}}$ LA and PLGA scaffolds, determined by micro CT, indicated that the scaffolds possess porosities as high as $78 \%$; the scaffolds produced from PLGA with high glycolic acid content had a lower porosity (Table 2 , entry 8 ). In addition, the scaffolds generated from polymers with low molecular weight, e.g. PLGA 85:15(15 KD) and PLGA 75:25(13 KD) appeared to be the most fragile of the whole set.

The critical parameters for controlling foam development in a $\mathrm{CO}_{2}$ foaming process are the concentration of $\mathrm{CO}_{2}$ in the polymer and the rate of $\mathrm{CO}_{2}$ escaping from the polymer (Stafford et al., 1999). These are closely related to the solubility of $\mathrm{CO}_{2}$ in the polymers, which is dependent upon the molecular structure and morphology of the polymers. Recent studies have demonstrated that $\mathrm{CO}_{2}$ has much lower solubility in semicrystalline polymers than in amorphous polymers due to the free volume effect (Shieh et al., 1996a, Shieh et al., 1996b, Oliverira et al., 2006b). Oliveira et al. (2006a,

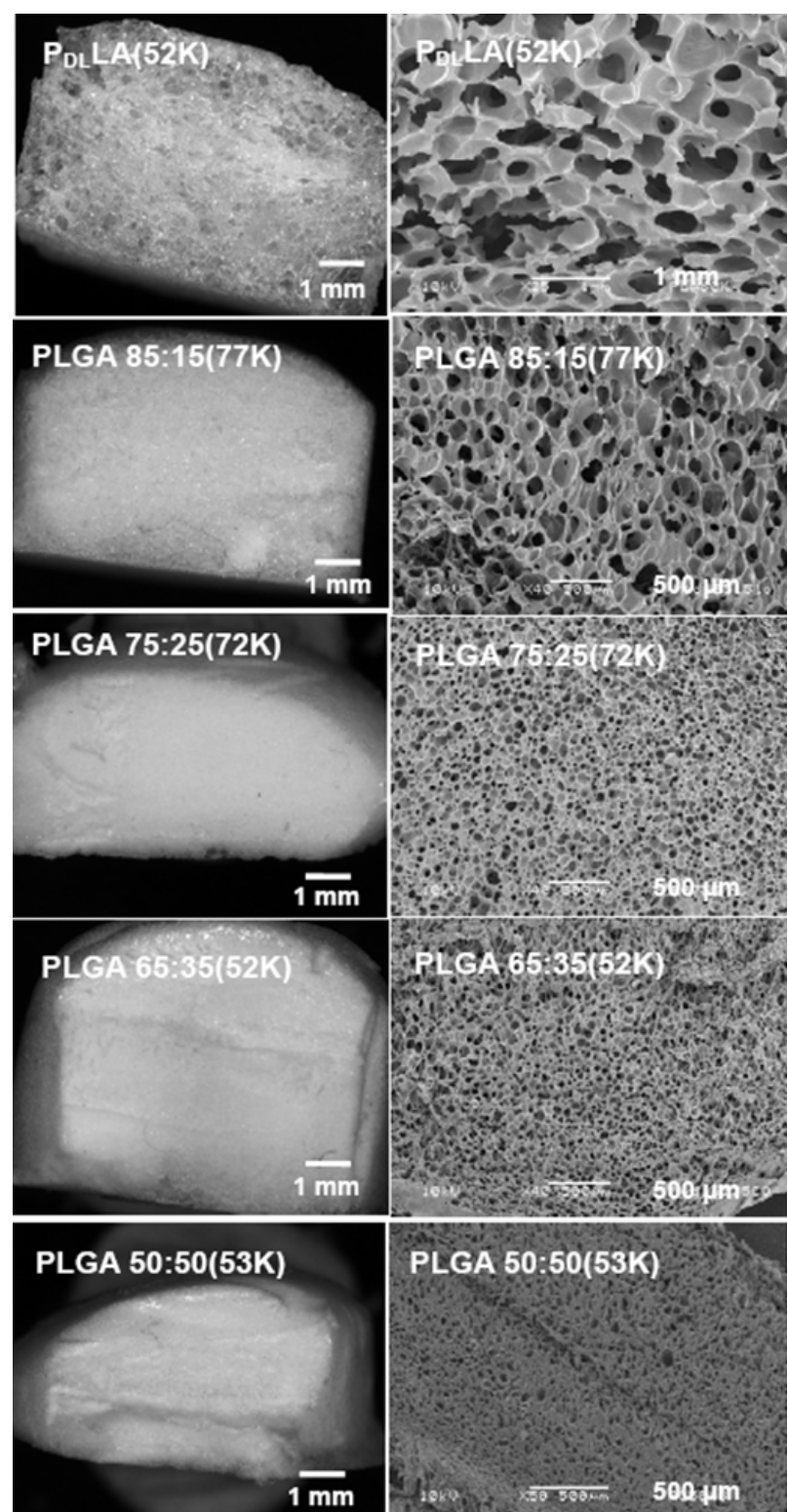

Figure 2: The effect of polymer composition on the morphology of $\mathrm{P}_{\mathrm{DL}}$ LA and PLGA scaffolds: Optical microscopy images are in the left column and SEM images are in the right column. Processing conditions: $\mathrm{T}=35^{\circ} \mathrm{C}, \mathrm{P}=230 \mathrm{bar}, \mathrm{FT}=20$ minutes, $\mathrm{ST}=60$ minutes, $\mathrm{VT}=60$ minutes. Note, the pore size decreases with increasing glycolic acid content from ca. 580 to $40 \mu \mathrm{m}$ (Table 3, entries 1, 3, 5, 6, 8). 
(a)

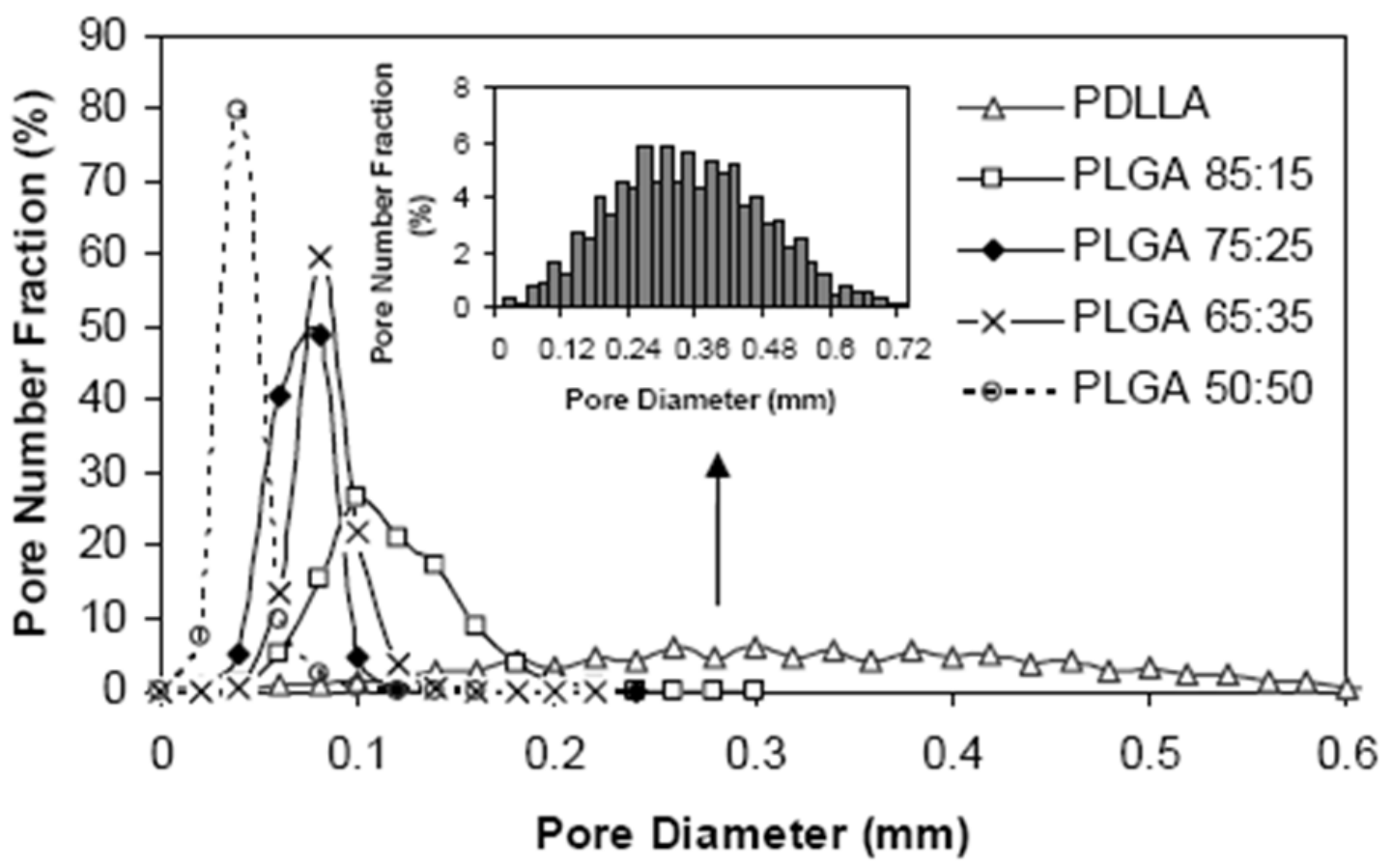

(b)
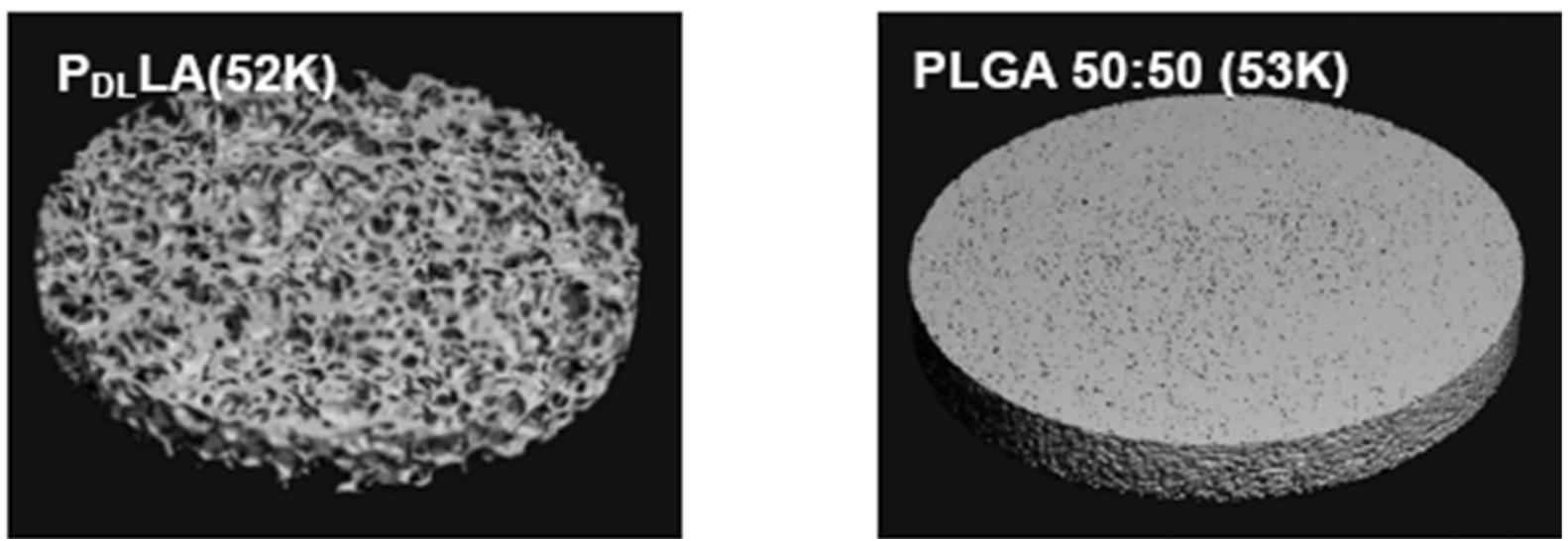

Figure 3: Scaffolds fabricated with $\mathrm{P}_{\mathrm{DL}}$ LA(52K), PLGA 85:15(77K), PLGA 75:25(72K), PLGA 65:35(52K), and PLGA 50:50(53K) polymers with (a) pore size distribution determined by Micro CT and (b) Micro CT 3-D images. Processing conditions: $\mathrm{T}=35^{\circ} \mathrm{C}, \mathrm{P}=230$ bar, $\mathrm{FT}=20$ minutes, $\mathrm{ST}=60$ minutes, $\mathrm{VT}=60$ minutes.

$2006 \mathrm{~b}$ ) found that the L:D ratio played a dominant role in $\mathrm{CO}_{2}$ sorption in PLA and their results indicated that $\mathrm{CO}_{2}$ was more soluble in PLA 80:20 (amorphous) than in PLA 98:2 (semi-crystalline). Therefore, $\mathrm{CO}_{2}$ should have lower solubility in crystalline poly(L-lactic acid) (PLLA) than in the amorphous $\mathrm{P}_{\mathrm{DL}}$ LA (L:D ratio 50:50) used in this study. Nalawade et al. (2006) reported that polymers with ether groups displayed stronger interactions with $\mathrm{CO}_{2}$ than polyesters. The affinity of $\mathrm{CO}_{2}$ with polyesters is largely due to the interaction of $\mathrm{CO}_{2}$ molecules with the carbonyl group on the polymer chains (Kazarian et al., 1996, Liu et al., 2007). It was found that the solubility of $\mathrm{CO}_{2}$ in PLGA copolymers decreased with the increase in the glycolic acid content (Liu et al., 2007). To compare LA and GA molecular structures, it shows that LA possesses an extra methyl group which could lead to at least two-opposing consequences. One is to increase the steric hindrance and then lower the interaction between the carbonyl group and the $\mathrm{CO}_{2}$ molecules, whereas the other one is to increase the available free volume in the matrix due to the steric effect. It was hypothesized that the latter factor plays a dominant role in determining the $\mathrm{CO}_{2}$ behaviour in PLGA (Liu et al., 2007), leading to a higher solubility for PLGA with a high LA content. Moreover, as a result of the viscosity dependence, the molecular weight and polydispersity of the polymer should influence the structure of the foam developed. During the polymer expansions followed by the depressurization, the long chains (high molecular weight) entangle to lock $\mathrm{CO}_{2}$ in; whereas the short chains (low molecular weight) allow easier escape of $\mathrm{CO}_{2}$ from the polymer, therefore promote rapid pore growth leading to larger pores and the fragile structure. 

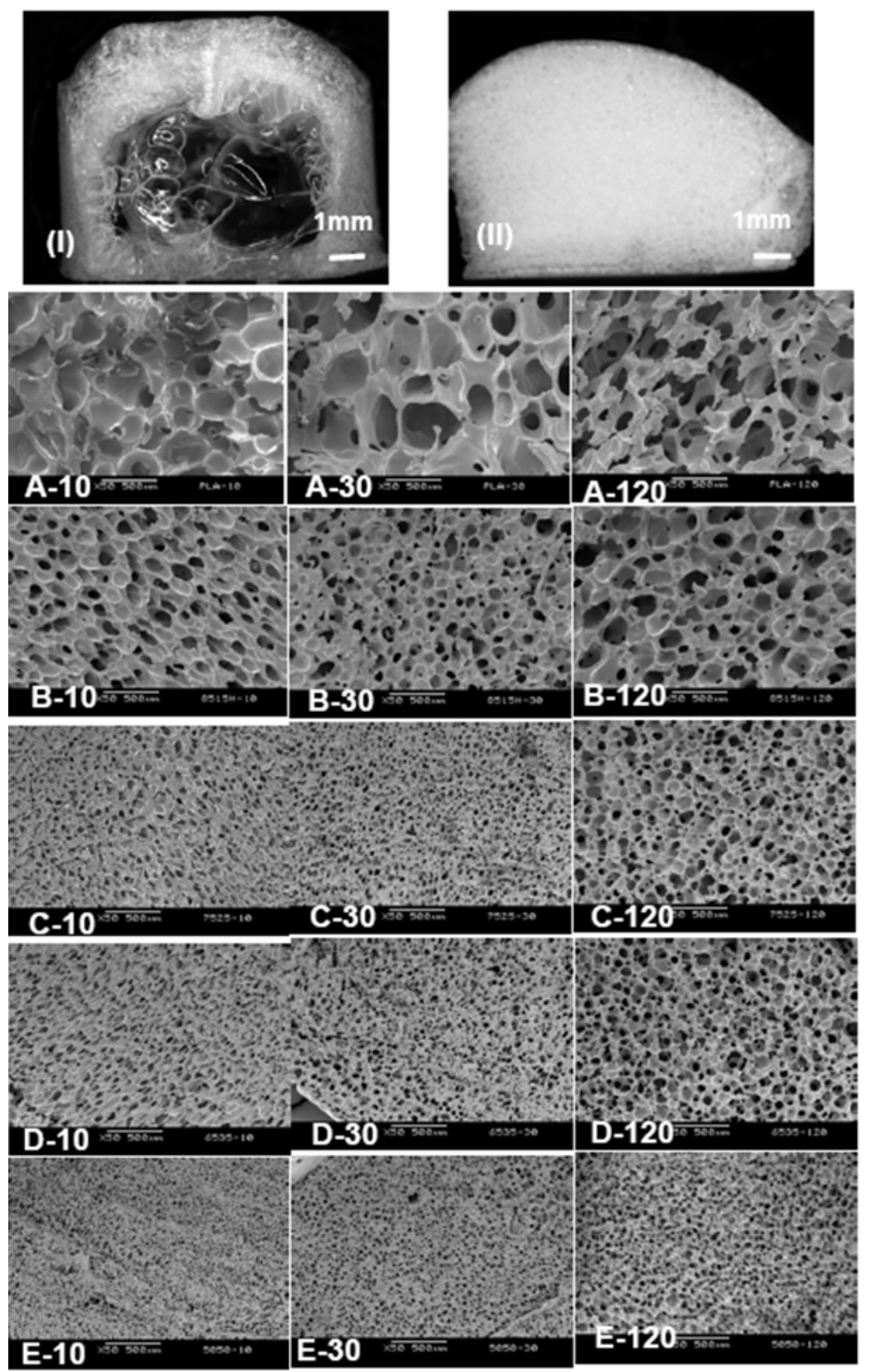

\section{E-10 ख0 500:4}

$-30$

Figure 4: SEM and optical microscopy images for $\mathrm{P}_{\mathrm{DL}}$ LA and PLGA scaffolds fabricated at different venting rate (VT $=10,30,120$ minutes). Other processing conditions: $\mathrm{T}=35^{\circ} \mathrm{C}, \mathrm{P}=230$ bar, $\mathrm{FT}=20$ minutes, $\mathrm{ST}=60$ minutes. A: $P_{D L}$ LA(52K); B: PLGA 85:15(77K); C: PLGA 75:25(72K); D: PLGA 65:35(52K); E: PLGA 50:50(53K). Note, at fast venting (2 minutes), non-uniform large pores were generated (I); at slow venting (120 minutes), uniform and more open pores were generated (II). In addition, the pore size decreases from A to E (indicating by the vertical arrow), and increases with venting time from 10 to 120 minutes (indicating by the horizontal arrow). Scale bar for all SEM images is $500 \mu \mathrm{m}$. 

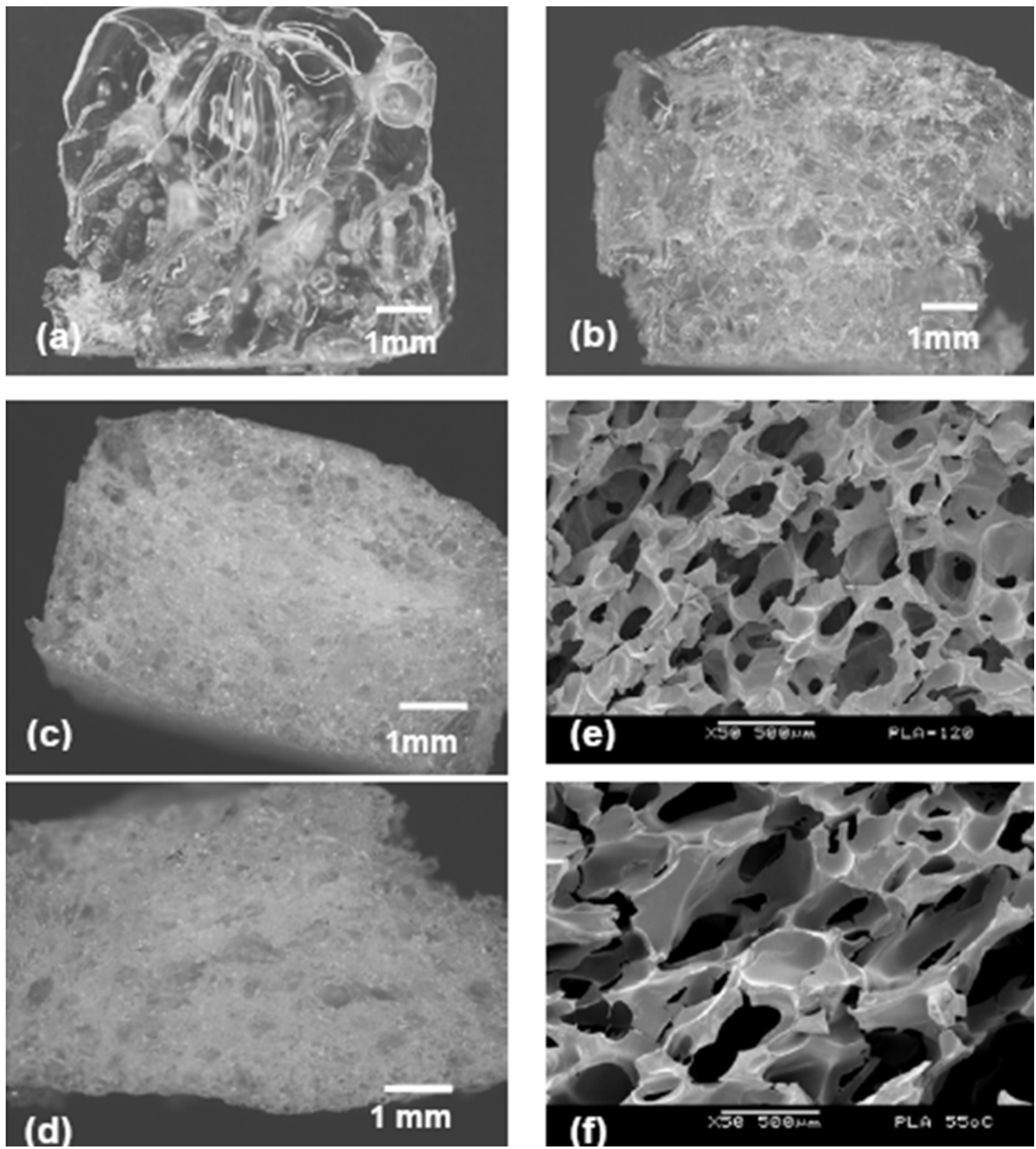

Figure 5: Images obtained by optical microscopy (a-d) and SEM (e,f) for $\mathrm{P}_{\mathrm{DL}} \mathrm{LA}(52 \mathrm{~K})$ scaffolds fabricated at different temperatures with (a) $5{ }^{\circ} \mathrm{C}$; (b) $25^{\circ} \mathrm{C}$; (c,e) $35^{\circ} \mathrm{C}$; (d,f) $55^{\circ} \mathrm{C}$. Processing conditions: $\mathrm{P}=230$ bar, $\mathrm{FT}=20$ minutes, $\mathrm{ST}=60$ minutes, $\mathrm{VT}=120$ minutes. Scale bar for SEM images is $500 \mu \mathrm{m}$.

Effect of processing conditions on the morphology of $P_{\text {DL }}$ LA and PLGA scaffolds

It is well known that the solubility of $\mathrm{CO}_{2}$ in polymers, the viscosity of swollen polymer, the nucleation density and the rate at which the $\mathrm{CO}_{2}$ diffuses from the matrix to the growing pores are all dependent upon the processing conditions, e.g. temperature, pressure, pressure drop, and depressurisation rate (Arora et al., 1998; Goel and Beckman, 1994a, 1994b; Sproule et al., 2004; Stafford et al., 1999). Therefore, the resulting foam structures can be controlled by manipulating these processing conditions. In this work, five polymer samples with similar molecular weight ca. $50-80 \mathrm{KD}$ but different compositions, i.e. $\mathrm{P}_{\mathrm{DL}}$ LA(52K), PLGA 85:15(77K), PLGA 75:25(72K), PLGA 65:35(52K), and PLGA 50:50(53K), were employed to study the effect of these parameters on the foam structures.

Effect of depressurisation rate. A series of experiments were carried out in which the rate of depressurisation was varied while holding the soaking conditions constant at $35^{\circ} \mathrm{C}$ and 230 bar for 1 hour. When depressurisation occurred rapidly at 2 and 5 minutes, the scaffolds typically displayed a non-uniform structure (Figure 4I) caused by temperature drop and phase 

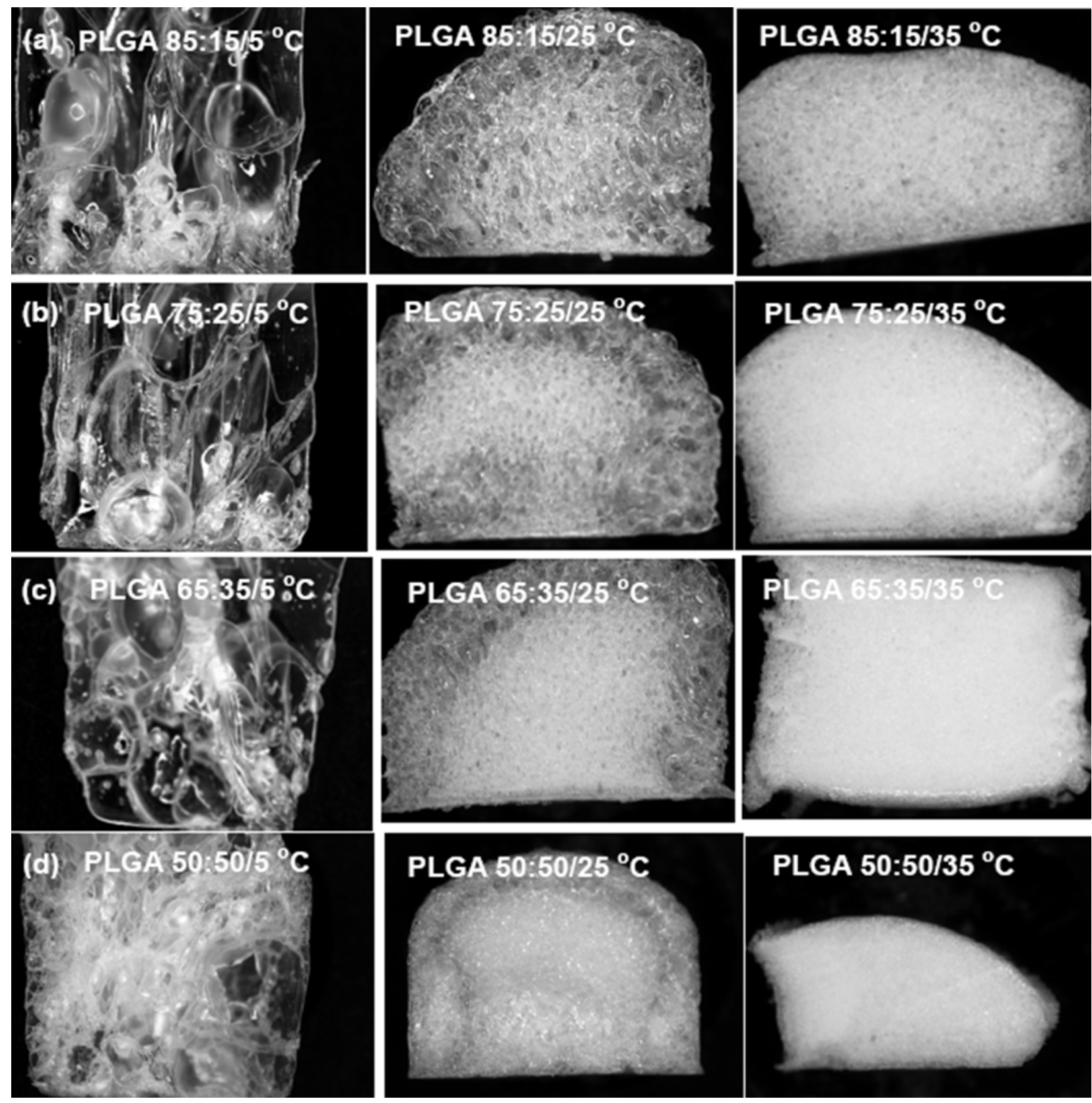

Figure 6: Optical microscopy images for PLGA scaffolds prepared at 5, 25, and $35^{\circ} \mathrm{C}$. (a) PLGA 85:15(77K); (b) PLGA 75:25(72K); (c) PLGA 65:35(52K); (d) PLGA 50:50(53K). Fabrication conditions: $\mathrm{P}=230$ bar, FT $=20$ minutes, $\mathrm{ST}=60$ minutes, $\mathrm{VT}=120$ minutes. The diameter of the scaffolds is $c a .10 \mathrm{~mm}$.

separation of the system as discussed in the visual observation section. This contrasts with the uniform porous structures obtained by the well controlled slow venting process (Figure 4II). The rate of $\mathrm{CO}_{2}$ release and the polymer relaxation are interdependent. A greater pressure drop rate resulted in higher supersaturation, leading to a greater nucleation rate. Decreasing the venting rate to 120 minutes permits the nucleation sites to grow into larger pores, whilst also allowing the pores to coalesce into more open structures (Figure 4, A-120, B-120, C-120, D-120, E-120) than those where depressurisation was more rapid, i.e. 10 minutes (Figure 4, A-10, B-10, C-10, D-10, E-10) and 30 minutes (Figure 4, A-30, B-30, C-30, D-30, E-30). These data agree with the published PMMA/CO $($ Goel and Beckman, 1994a, 1994b; Sproule et al., 2004) and PS/CO 2 systems (Arora et al., 1998).
Effect of soaking temperature. Experiments varying the foaming temperature, while holding other variables constant, show that the temperatures below supercritical point $\left(5\right.$ and $\left.25^{\circ} \mathrm{C}\right)$ produce scaffolds with large and nonuniform pores from both $\mathrm{P}_{\mathrm{DL}}$ LA homopolymers (Figure 5) and PLGA copolymers (Figure 6). At the temperatures above the supercritical point $\left(35\right.$ and $\left.55^{\circ} \mathrm{C}\right)$, uniform pores were formed. In addition, a higher temperature $\left(55^{\circ} \mathrm{C}\right)$ led to larger and more open pores than a lower temperature $\left(35^{\circ} \mathrm{C}\right)$ (Figure 7), which is in agreement with the $\mathrm{PS} / \mathrm{CO}_{2}$ system (Arora et al., 1998). The solubility of $\mathrm{CO}_{2}$ in the polymers increases with decreasing temperature at a constant pressure because of the increase of $\mathrm{CO}_{2}$ density. However, the diffusion rate of $\mathrm{CO}_{2}$ in the polymers is low at a low temperature. Therefore, it is hypothesised that $\mathrm{CO}_{2}$ might not be distributed uniformly throughout the 

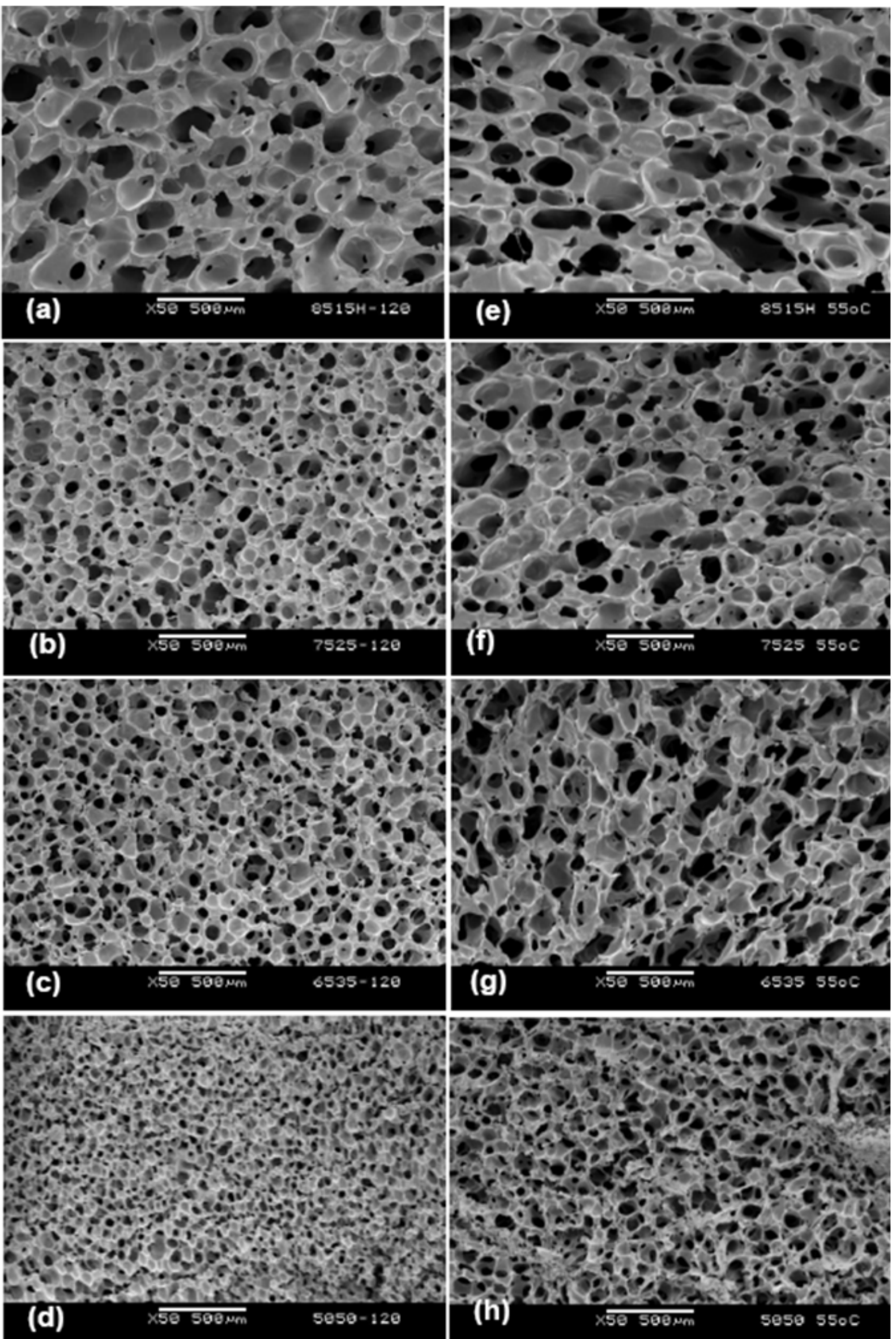

Figure 7: SEM images for PLGA scaffolds produced at $35^{\circ} \mathrm{C}$ (a-d) and $55^{\circ} \mathrm{C}(\mathrm{e}-\mathrm{h})(\mathrm{a}, \mathrm{e})$ : PLGA 85:15(77K); (b,f): PLGA 75:25(72K); (c,g): PLGA 65:35(52K); (d,h) PLGA 50:50(53K). Note, larger pores were formed at $55^{\circ} \mathrm{C}$ than those at $35^{\circ} \mathrm{C}$. Scale bar for all SEM images is $500 \mu \mathrm{m}$. 

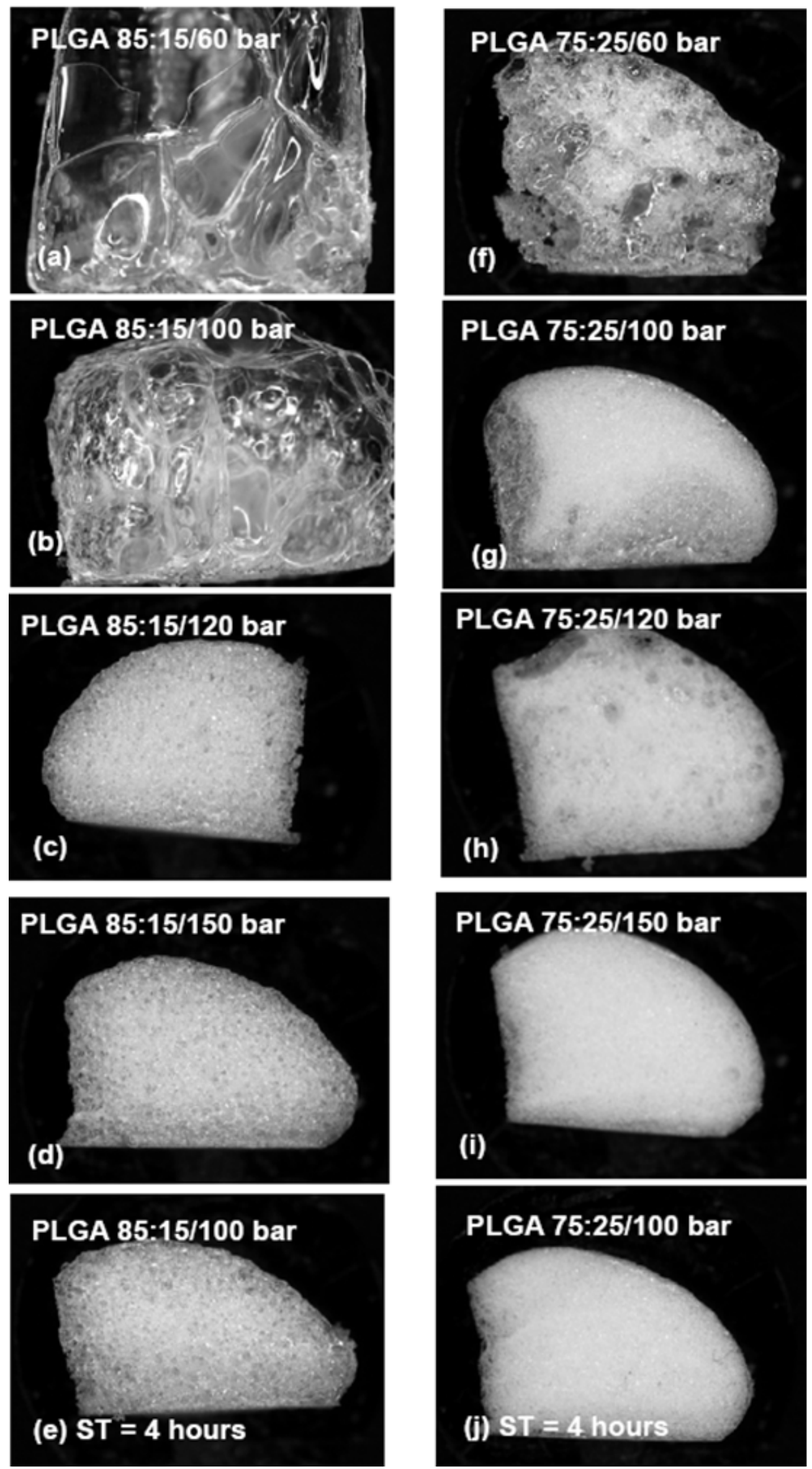

Figure 8: Optical microscopy images for PLGA 85:15(77K) (a-e) and PLGA 75:25 (72K) (f-j) scaffolds fabricated at different pressures $(\mathrm{P})$ with $(\mathrm{a}, \mathrm{f}): 60$ bar; $(\mathrm{b}, \mathrm{g}): 100$ bar; $(\mathrm{c}, \mathrm{h}): 120$ bar; $(\mathrm{d}, \mathrm{i}): 150$ bar. Processing conditions: $\mathrm{T}=$ $35^{\circ} \mathrm{C}, \mathrm{FT}=20$ minutes, $\mathrm{ST}=60$ minutes, $\mathrm{VT}=120$ minutes. $(\mathrm{e}, \mathrm{j}): \mathrm{P}=100$ bar, $\mathrm{ST}=4$ hours, $\mathrm{T}=35^{\circ} \mathrm{C}, \mathrm{FT}=20$ minutes, $\mathrm{VT}=120$ minutes. 
swollen polymers within the soaking time (1 hour) at low temperatures. $\mathrm{A} \mathrm{CO}_{2}$ concentration gradient might exist, i.e. high $\mathrm{CO}_{2}$ concentration regions close to the interface with $\mathrm{CO}_{2}$. Whilst venting occurs, some regions may have been supersaturated earlier than others, leading to nonuniform nucleation sites. Also, at low temperatures, phase separation of $\mathrm{CO}_{2}$ occurs while venting. The combination of these effects may have led to non-uniform pores at low temperatures. Moreover, this also confirms that $\mathrm{CO}_{2}$ can depress the $\mathrm{T}_{\mathrm{g}}$ of these biomaterials to well below body temperature $\left(5^{\circ} \mathrm{C}\right)$. It is known that the diffusion coefficient of the swollen polymer increases with temperature, thus the time required to reach equilibrium decreases with temperature (Royer et al., 1999). Under high temperatures, the $\mathrm{CO}_{2}$ was uniformly distributed in the swollen polymers and there was no phase separation while venting. In addition, a higher diffusion rate of $\mathrm{CO}_{2}$ at $55^{\circ} \mathrm{C}$ allowed the pores to grow larger than those at $35^{\circ} \mathrm{C}$, as can be seen in Figure 7.

Effect of soaking pressure. The effect of the soaking pressure $(60,100,120$ and 150 bar) on the foam structure was studied at a constant temperature of $35^{\circ} \mathrm{C}$ and the same conditions for filling, soaking and venting (FT $=20$ minutes, $\mathrm{ST}=60$ minutes, $\mathrm{VT}=120$ minutes). Two PLGA copolymers, PLGA 85:15 (77K) (pellet) and PLGA 75:25 $(72 \mathrm{~K})$ (fine powder), were utilised. The images in Figure 8 show that the pore size of the scaffolds decreased with increasing soaking pressure (a to $\mathrm{d}$ for PLGA 85:15, $\mathrm{f}$ to $\mathrm{i}$ for PLGA 75:25). Singh et al. (2004) found the diffusion coefficient and equilibrium concentration of $\mathrm{CO}_{2}$ in PLGA increased with increasing pressure in an approximately linear relationship. Also, higher pressure was found to increase the dissolution of $\mathrm{CO}_{2}$ and, as a consequence, the $\mathrm{T}_{\mathrm{g}}$ was found to decrease more (Shieh et al., 1996b). Therefore, at a higher pressure, the amount of $\mathrm{CO}_{2}$ incorporated into the polymers is greater, and hence the substrate is more highly supersaturated upon release of the pressure. These greater super saturation pressures lead to higher nucleation densities and hence smaller pores.

Effect of soaking time. To study the effect of soaking time on scaffold formation, the scaffolds were fabricated using a pellet sample PLGA 85:15 (Figure 8e) and a powder sample PLGA 75:25 (Figure 8j) at a pressure of 100 bar and a soaking time of 4 hours; other processing conditions remained constant as those used during the 1 hour soak, i.e. $\mathrm{T}=35^{\circ} \mathrm{C}, \mathrm{FT}=20$ minutes and $\mathrm{VT}=120$ minutes. Compared to the scaffolds produced with a shorter soaking time (1 hour) (Figure 8b,g), the scaffolds produced after a longer soaking time clearly show a tight distribution of smaller pores rather than the broader distribution of large pores. As discussed in the previous section, $\mathrm{CO}_{2}$ might not be distributed uniformly throughout the swollen polymers within a short soaking time (1 hour) at low pressures, which may lead to a $\mathrm{CO}_{2}$ concentration which is higher at the region close to the interface with $\mathrm{CO}_{2}$ than inside the bulk of the polymer. However, a longer soaking time allows $\mathrm{CO}_{2}$ to more efficiently diffuse into the polymers and distribute uniformly, leading to more uniform porous scaffolds after venting (Figure 8e, j). Moreover, the equilibrium time required also depends on the nature of the sample, i.e. sample size and sample form based upon the surface area/volume ratio (Shieh et al., 1996a). Shorter equilibrium times are needed for the powder sample (Figure 8, PLGA 75:25) than the pellet sample (Figure 8, PLGA 85:15).

\section{Conclusions}

The pore size and structure of the $\mathrm{P}_{\mathrm{DL}}$ LA and PLGA porous scaffolds produced using $\mathrm{scCO}_{2}$ can be tailored by altering the processing conditions. A higher pressure and a longer soaking time allowed more $\mathrm{CO}_{2}$ molecules to diffuse into the polymer matrix, leading to a higher nucleation density and hence the production of smaller pores. Higher temperatures produced foams with larger pores because increased diffusion rates facilitated pore growth. In addition, reducing the rate of depressurisation allowed a longer period for pore growth and therefore larger pores were formed than with rapid depressurisation. The pore size of scaffolds also decreased with increasing glycolic acid content in the PLGA copolymers. This knowledge empowers the definition of processing conditions to tailor the pore size and structure of scaffolds for potential application as controlled release devices for growth factor delivery in Tissue Engineering.

\section{Acknowledgements}

We gratefully acknowledge EPSRC for funding on this Grand Challenge project. We also thank Dr P. Ginty, Dr M. Heyde, Mr S. Pygall and Dr C. Melia, Mr R. G. M. Wilson, Mr P. A. Fields and Mr M. P. Dellar for scientific discussions and technical support. S.M.H. is a Royal Society Wolfson Research Merit Award holder.

\section{References}

Arora KA, Lesser AJ, McCarthy TJ (1998) Preparation and characterization of microcellular polystyrene foams processed in supercritical carbon dioxide. Macromolecules 31: 4614-4620.

Barry JJA, Gidda HS, Scotchford CA, Howdle SM (2004) Porous methacrylate scaffolds: supercritical fluid fabrication and in vitro chondrocyte responses. Biomaterials 25: 3559-3568.

Barry JJA, Silva M, Popov VK, Shakesheff KM, Howdle SM (2006) Supercritical carbon dioxide: putting the fizz into biomaterials. Phil Trans Royal Soc A-Math Phys Engg Sci 364: 249-261.

Cooper AI (2001) Recent developments in materials synthesis and processing using supercritical $\mathrm{CO}_{2}$. $\mathrm{Adv}$ Mater 13: 1111-1114.

Furno F, Licence P, Howdle SM, Poliakoff M (2003) Recent developments in the use of supercritical $\mathrm{CO}_{2}$ in synthetic organic chemistry. Act Chim: 4-5: 62-66.

Goel SK, Beckman EJ (1994a) Generation of microcellular polymeric Foams using supercritical carbon- 
dioxide. 1. Effect of pressure and temperature on nucleation. Polymer Engg Sci 34: 1137-1147.

Goel SK, Beckman EJ (1994b) Generation of microcellular polymeric foams using supercritical carbondioxide. II. Cell-growth and skin formation. Polymer Engg and Sci 34: 1148-1156.

Harris LD, Kim BS, Mooney DJ (1998) Open pore biodegradable matrices formed with gas foaming. J Biomed Mater Res 42: 396-402.

Heyde M, Partridge K, Howdle S, Oreffo R, Garnett M, Shakesheff K (2007) Development of a slow non-viral DNA release system from $\mathrm{P}_{\mathrm{DL}}$ LA scaffolds fabricated using a supercritical $\mathrm{CO}_{2}$ technique. Biotechnol Bioeng 98: 679693.

Hile DD, Amirpour ML, Akgerman A, Pishko MV (2000) Active growth factor delivery from poly(D,Llactide-co-glycolide) foams prepared in supercritical $\mathrm{CO}_{2}$. J Controlled Rel 66: 177-185.

Hile DD, Pishko MV (2004) Solvent-free protein encapsulation within biodegradable polymer foams. Drug Delivery 11: 287-293.

Hou QP, Grijpma DW, Feijen J (2003) Porous polymeric structures for tissue engineering prepared by a coagulation, compression moulding and salt leaching technique. Biomaterials 24: 1937-1947.

Howard D, Partridge K, Yang XB, Clarke NMP, Okubo Y, Bessho K, Howdle SM, Shakesheff KM, Oreffo ROC (2002) Immunoselection and adenoviral genetic modulation of human osteoprogenitors: in vivo bone formation on PLA scaffold. Bioch Biophys Res Commun 299: 208-215.

Howdle SM, Watson MS, Whitaker MJ, Popov VK, Davies MC, Mandel FS, Wang JD, Shakesheff KM (2001) Supercritical fluid mixing: preparation of thermally sensitive polymer composites containing bioactive materials. Chem Commun 1: 109-110.

Hutmacher DW (2000) Scaffolds in tissue engineering bone and cartilage. Biomaterials 21: 2529-2543.

Jang JH, Shea LD (2003) Controllable delivery of nonviral DNA from porous scaffolds. J Controlled Rel 86: 157-168.

Kazarian SG, Vincent MF, Eckert CA (1996) Infrared cell for supercritical fluid-polymer interactions. Rev Sci Instr 67: 1586-1589.

Kim TK, Yoon JJ, Lee DS, Park TG (2006) Gas foamed open porous biodegradable polymeric microspheres. Biomaterials 27: 152-159.

Langer R (1998) Drug delivery and targeting. Nature 392: 5-10.

Liu DH, Tomasko DL (2007) Carbon dioxide sorption and dilation of poly(lactide-co-glycolide). J Supercrit Fluids 39: 416-425.

Lu L, Peter SJ, Lyman MD, Lai HL, Leite SM, Tamada JA, Uyama S, Vacanti JP, Langer R, Mikos AG (2000) In vitro and in vivo degradation of porous poly(DL-lacticco-glycolic acid) foams. Biomaterials 21: 1837-1845.

Mooney DJ, Baldwin DF, Suh NP, Vacanti LP, Langer R (1996) Novel approach to fabricate porous sponges of poly(D,L-lactic- co-glycolic acid) without the use of organic solvents. Biomaterials 17: 1417-1422.
Murphy WL, Peters MC, Kohn DH, Mooney DJ (2000) Sustained release of vascular endothelial growth factor from mineralized poly(lactide-co-glycolide) scaffolds for tissue engineering. Biomaterials 21: 2521-2527.

Murphy WL, Dennis RG, Kileny JL, Mooney DJ (2002) Salt fusion: An approach to improve pore interconnectivity within tissue engineering scaffolds. Tissue Engg 8: 43-52.

Nalawade SP, Picchioni F, Marsman JH, Janssen L (2006) The FT-IR studies of the interactions of $\mathrm{CO}_{2}$ and polymers having different chain groups. J Supercrit Fluids 36: 236-244.

Nam YS, Yoon JJ, Park TG (2000) A novel fabrication method of macroporous biodegradable polymer scaffolds using gas foaming salt as a porogen additive. J Biomed Mater Res 53: 1-7.

Partridge K, Yang XB, Clarke NMP, Okubo Y, Bessho K, Sebald W, Howdle SM, Shakesheff KM, Oreffo ROC (2002) Adenoviral BMP-2 gene transfer in mesenchymal stem cells: In vitro and in vivo bone formation on biodegradable polymer scaffolds. Biochem Biophys Res Commun 292: 144-152.

Oliveira NS, Dorgan J, Coutinho JAP, Ferreira A, Daridon JL, Marrucho IM (2006a) Gas solubility of carbon dioxide in poly(lactic acid) at high pressures. J Polymer Sci B-Polymer Phys 44: 1010-1019.

Oliveira NS, Goncalves CM, Coutinho JAP, Ferreira A, Dorgan J, Marrucho IM (2006b) Carbon dioxide, ethylene and water vapor sorption in poly(lactic acid). Fluid Phase Equil 250: 116-124.

Quirk RA, France RM, Shakesheff KM, Howdle SM (2004) Supercritical fluid technologies and tissue engineering scaffolds. Curr Opin Solid State Mater Sci 8: 313-321.

Riddle KW, Mooney DJ (2004) Role of poly(lactideco-glycolide) particle size on gas-foamed scaffolds. J Biomaterials Sci-Polymer Ed 15: 1561-1570.

Royer JR, DeSimone JM, Khan SA (1999) Carbon dioxide-induced swelling of poly( dimethylsiloxane). Macromolecules 32: 8965-8973.

Sheridan MH, Shea LD, Peters MC, Mooney DJ (2000) Bioadsorbable polymer scaffolds for tissue engineering capable of sustained growth factor delivery. J Controlled Rel 64: 91-102.

Shieh YT, Su JH, Manivannan G, Lee PHC, Sawan SP, Spall WD (1996a) Interaction of supercritical carbon dioxide with polymers. 1. Crystalline polymers. J Appl Polymer Sci 59: 695-705.

Shieh YT, Su JH, Manivannan G, Lee PHC, Sawan SP, Spall WD (1996b) Interaction of supercritical carbon dioxide with polymers. 2. Amorphous polymers. J Appl Polymer Sci 59: 707-717.

Singh L, Kumar V, Ratner BD (2004) Generation of porous microcellular $85 / 15$ poly ((DL)-lactide-coglycolide) foams for biomedical applications. Biomaterials 25: 2611-2617.

Sosnowski S, Wozniak P, Lewandowska-Szumiel M (2006) Polyester scaffolds with bimodal pore size distribution for tissue engineering. Macromol Biosc 6: 425434. 
Sproule TL, Lee JA, Li HB, Lannutti JJ, Tomasko DL (2004) Bioactive polymer surfaces via supercritical fluids. J Supercrit Fluids 28: 241-248.

Stafford CM, Russell TP, McCarthy TJ (1999) Expansion of polystyrene using supercritical carbon dioxide: Effects of molecular weight, polydispersity, and low molecular weight components. Macromolecules 32: 7610-7616.

Tomasko DL, Li HB, Liu DH, Han XM, Wingert MJ, Lee LJ, Koelling KW (2003) A review of $\mathrm{CO}_{2}$ applications in the processing of polymers. Industr Engg Chem Res 42: 6431-6456.

Watson MS, Whitaker MJ, Howdle SM, Shakesheff KM (2002) Incorporation of proteins into polymer materials by a novel supercritical fluid processing method. Adv Mater 14: 1802-1804.

Woods HM, Silva M, Nouvel C, Shakesheff KM, Howdle SM (2004) Materials processing in supercritical carbon dioxide: surfactants, polymers and biomaterials. J Mater Chem 14: 1663-1678.

Yang XB, Green D, Roach HI, Anderson HC, Howdle SM, Shakesheff KM, Oreffo ROC (2006) The effect of an admix of bone morphogenetic proteins on human osteoprogenitor activity in vitro and in vivo. Tissue Engg 12: 1002-1003.

Yang XBB, Whitaker MJ, Sebald W, Clarke N, Howdle SM, Shakesheff KM, Oreffo ROC (2004) Human osteoprogenitor bone formation using encapsulated bone morphogenetic protein 2 in porous polymer scaffolds. Tissue Engg 10: 1037-1045.

\section{Discussion with Reviewers}

J. Darr: Why did you select this pressure and temperature range for your experiments?

Authors: The temperature range for our experiments (5$55^{\circ} \mathrm{C}$ ) is selected to be close to ambient temperature in order to limit denaturation of the incorporated bioactives. The determination of the pressure range for our experiments is based on our previous published results. It was found that the use of a high pressure (170-230 bar) can dramatically reduce the prolonged soaking time to 2 hours and produce scaffolds with desired pore size and porosity. However, there is no doubt that using a lower processing pressure is more attractive from both a practical and an economical point of view. Therefore, we selected 230 bar as the highest pressure for our experiments, while the lowest pressure (60 bar) was chosen as a point below the $\mathrm{CO}_{2}$ critical pressure (73.8 bar).

J. Darr: Does it make any difference to pore sizes/ distributions if it is above the critical point?

Authors: The key in a gas foaming process is pore nucleation and growth, which determines the final porous structure (pore size/distribution, porosity, and interconnectivity). This pore nucleation and growth are mainly influenced by the amount of $\mathrm{CO}_{2}$ dissolved in the polymer, and the rate of $\mathrm{CO}_{2}$ diffusing within and escaping from the polymer. The $\mathrm{scCO}_{2}$ has a higher density than gaseous $\mathrm{CO}_{2}$ and a higher diffusivity than liquid $\mathrm{CO}_{2}$. Therefore, it certainly does affect the formation of a porous structure if it is above or below the critical point. However, the final porous structures of the resultant scaffolds are influenced by many fabrication conditions as well as pressure and temperature, such as soaking time and venting rate and type of polymer.

J. Darr: Did you look at any other molecular weights for the polymers and how would this affect pore sizes etc?

Authors: Yes. We have investigated the effect of molecular weight on morphology of $\mathrm{P}_{\mathrm{DL}}$ LA scaffolds. The results will be reported in a follow-up paper, which is in the final stage of drafting.

J. Darr: How does porosity affect drug release from these materials?

Authors: The pore structure of scaffolds, including pore size, porosity and interconnectivity, strongly influences cell growth behaviour and drug release profile. A high porosity and interconnectivity within scaffolds could enhance drug release from the matrix. Our research group has reported the studies on BMP-2 growth factor release (Yang et al., 2004) and cell growth behaviour using $P_{D L}$ LA scaffolds produced by this $\mathrm{scCO}_{2}$ foaming technique. The research on using PLGA scaffolds for growth factor release is currently on-going at Nottingham.

P. Layrolle: The authors mentioned several times the solubility of $\mathrm{scCO}_{2}$ into the polymers. Is $\mathrm{scCO}_{2}$ fluid not a solvent for polymers? Then, the solubility of polymers into $\mathrm{scCO}_{2}$ should be considered. Please comment.

Authors: PLA and PLGA polymers have negligible solubility in $\mathrm{scCO}_{2}$ under the conditions employed in this research. Indeed, others (Conway et al., 2001) have shown that to solubilise even low molecular weight PLA in $\mathrm{scCO}_{2}$ requires extremely forcing conditions.

P. Layrolle: It was found that high pressure and long soaking times increased the diffusion of $\mathrm{ScCO}_{2}$ into the polymer matrix leading to numerous nucleation sites and thus, produced numerous small pores. Where the nucleation of $\mathrm{CO}_{2}$ gas takes place in the polymer matrix? Does the nucleation sites relate to the chemistry or chain length of polymers?

Authors: The number of nucleation sites is determined by the concentration and the solubility of $\mathrm{CO}_{2}$ in the polymers, as well as the rate of depressurization. Due to depressurization, the polymer/ $\mathrm{CO}_{2}$ mixture reaches saturation, at which the $\mathrm{CO}_{2}$ starts escaping from the polymer as gas. This phase separation results in the nucleation, which takes place at the interface of polymer matrix and $\mathrm{CO}_{2}$ gas phase. The nucleation sites might relate to the chemistry or chain length of polymers due to the interaction between $\mathrm{CO}_{2}$ and the polymer. However, we don't have evidence to support this hypothesis yet.

P. Layrolle: High temperatures produce scaffolds with large pores due to high diffusion of $\mathrm{CO}_{2}$. Would it be possible to oscillate the system in temperature to produce 
scaffolds with bimodal pore size? Bimodal pore size might be of interest for sorting cells and molecules. Please comment.

Authors: This paper has demonstrated that pore size and structure of the $\mathrm{P}_{\mathrm{DL}}$ LA and PLGA scaffolds can be tailored by altering processing conditions. The knowledge contributed by this research is aimed at allowing us to define the processing conditions and to tailor the pore size and structure of scaffolds for potential applications as controlled release devices for growth factor delivery. It might well be possible to produce scaffolds with bimodal pore size by a two-step venting processing either using two temperatures or perhaps two venting rates.

P. Layrolle: The pore size interconnectivity in scaffolds is extremely important for permeability of body fluids, cells and tissues. However, this parameter has not been investigated in the present study. Please comment.

Authors: The interconnectivity of scaffolds is one of the most important characteristics in terms of biological applications. SEM images can be used to demonstrate the interconnectivity of porous scaffolds qualitatively. In our paper, the SEM images have been used to demonstrate a more open and interconnected pore structure for $\mathrm{P}_{\mathrm{DL}} \mathrm{LA}$ scaffold than for PLGA scaffolds (Figure 2).

P. Layrolle: Liu et al. (2007) have shown by FTIR spectroscopy that $\mathrm{CO}_{2}$ molecules interact with carbonyl group in polyesters. In the present study, the pore size decreased with the GA content in PLAGA polymers. The authors postulated that it may be due to an extra methyl group in GA structure leading to steric hindrance diminishing the interaction between $\mathrm{CO}_{2}$ and carbonyl groups or that would create more free volume between chains due to a steric effect. How this possible steric hindrance could be shown? Would it possible to use molecular dynamic simulations?

Authors: We don't have expertise on molecular dynamic simulations. However, we agree with the reviewer that a fundamental study at the molecular level using molecular dynamic simulations could be a feasible approach for the illustration of steric hindrance and free volume theory.

P. Layrolle: The authors would like to use these foamed polymers for releasing growth factors. What are the growth factors that they would like to introduce? How are the growth factors loaded and where are they located in the polymers using $\mathrm{scCO}_{2}$ processing? How the growth factor will be released from the polymer matrix? Is it by diffusion, degradation or cellular activity?
Authors: BMP2 growth factor is one of our major interests. It can be loaded easily by mixing with the powdered polymer in the mould, and then the polymer loaded mould is placed in the high pressure autoclave for plasticization and foaming using $\mathrm{CO}_{2}$ under defined conditions. The growth factor is encapsulated within the polymer matrix and released from the matrix by both diffusion and degradation. Many more details of this process and the in vivo data we have obtained can be seen in our joint publications with collaborator Professor R.O.C. Oreffo (University of Southampton).

P. Layrolle: I would be happy to see some release experiments using growth factor or the behaviour of cells into these porous scaffolds.

Authors: Our research group has reported studies on growth factor release and cell growth behaviour using $\mathrm{P}_{\mathrm{DL}}$ LA scaffolds produced by $\mathrm{scCO}_{2}$ foaming. This includes BMP-2 growth factor delivery (Yang et al., 2004), where bone formation was observed due to the release of the osteoinductive protein BMP-2 from $\mathrm{P}_{\mathrm{DL}}$ LA scaffolds both in vitro and in vivo (Yang et al., 2004; Yang et al., 2006). These scaffolds have also been used to study adenoviral gene transfer into primary human bone marrow osteoprogenitor cells (Partridge et al., 2002; Howard et al., 2002). Very recently, polyamidoamine (PAA)/DNA complexes have been incorporated into supercritical $\mathrm{P}_{\mathrm{DL}} \mathrm{LA}$ scaffolds; these exhibited a slow release and extended gene expression profile (Heyde et al., 2007). The study of growth factor release using PLGA scaffolds is currently on-going in our research group.

T. Buckland: Please justify use of $\mu \mathrm{CT}$ and the lack of standard deviations for total porosity measurements given the importance of this parameter to biological performance. Authors: Our experimental results indicate a reproducible 2-3 \% of standard deviation on porosity evaluations by using $\mu \mathrm{CT}$ technique. $\mu \mathrm{CT}$ is a powerful technique for the evaluation of porosity by using 3-D construction; by contrast, SEM technique only allows 2-D image analysis. The standard deviation of porosity obtained by $\mu \mathrm{CT}$ has been added in the revised manuscript (Table 2).

\section{Additional Reference}

Conway SE, Byun HS, McHugh MA Wang JD, Mandel FS (2001) Poly(lactide-co-glycolide) solution behavior in supercritical $\mathrm{CO}_{2}, \mathrm{CHF}_{3}$, and $\mathrm{CHClF}_{2}$. J Appl Polymer Sci 80: 1155-1161. 